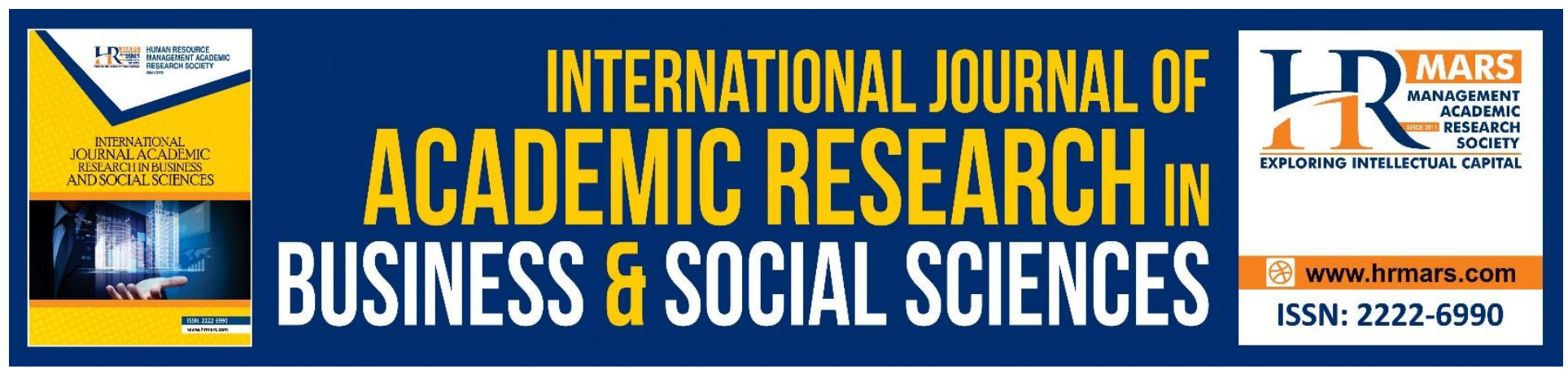

\title{
Collaborative Teaching between Special Education Teachers and Mainstream Teachers in Inclusive Education Program
}

Abdul Rahim Razalli, Abdul Talib Hashim, Nordin Mamat, Azli Ariffin

To Link this Article: http://dx.doi.org/10.6007/IJARBSS/v10-i8/7713

DOI:10.6007/IJARBSS/v10-i8/7713

Received: 16 May 2020, Revised: 20 June 2020, Accepted: 21 July 2020

Published Online: 16 August 2020

In-Text Citation: (Razalli, Hashim, Mamat, \& Ariffin, 2020)

To Cite this Article: Razalli, A. R., Hashim, A. T., Mamat, N., \& Ariffin, A. (2020). Collaborative Teaching between Special Education Teachers and Mainstream Teachers in Inclusive Education Program. International Journal of Academic Research in Business and Social Sciences. 10(8), 1055-1065.

Copyright: (C) 2020 The Author(s)

Published by Human Resource Management Academic Research Society (www.hrmars.com)

This article is published under the Creative Commons Attribution (CC BY 4.0) license. Anyone may reproduce, distribute, translate and create derivative works of this article (for both commercial and non-commercial purposes), subject to full attribution to the original publication and authors. The full terms of this license may be seen at: http://creativecommons.org/licences/by/4.0/legalcode

Vol. 10, No. 8, 2020, Pg. 1055 - 1065

http://hrmars.com/index.php/pages/detail/IJARBSS

JOURNAL HOMEPAGE

Full Terms \& Conditions of access and use can be found at http://hrmars.com/index.php/pages/detail/publication-ethics 


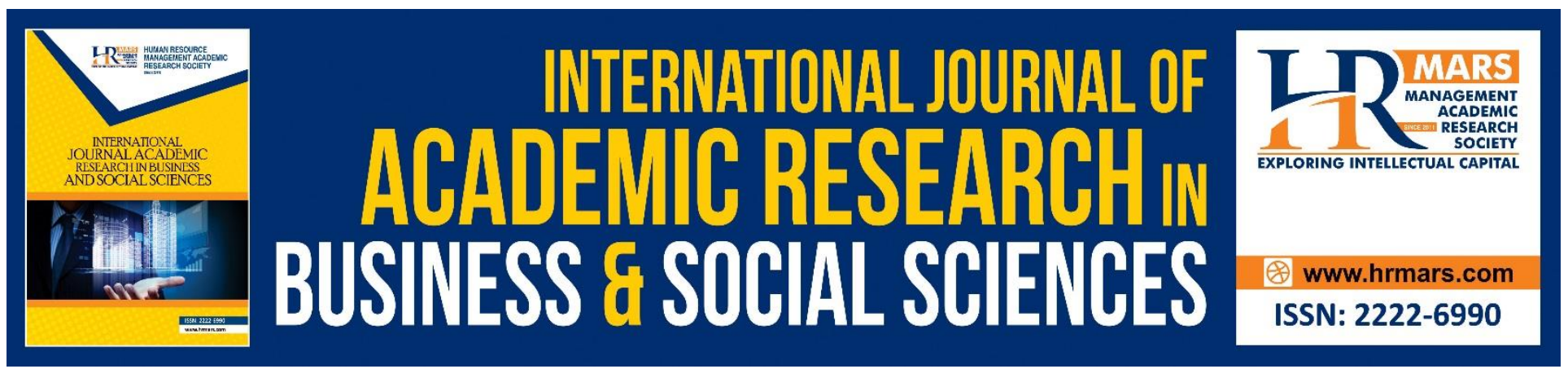

\title{
Collaborative Teaching between Special Education Teachers and Mainstream Teachers in Inclusive Education Program
}

\section{Abdul Rahim Razalli, Abdul Talib Hashim, Nordin Mamat, Azli Ariffin}

Faculty of Human Development, Sultan Idris Education University, 35900 Tanjong Malim, Perak

Email: rahim.r@fpm.upsi.edu.my, talib@fpm.upsi.edu.my,nordin@fpm.upsi.edu.my, azli@fpm.upsi.edu.my

\begin{abstract}
This study investigates collaboration in teaching between special education teachers (SET) and mainstream teachers (MT) for the implementation of inclusive education in schools. This study divides the context of collaborative teaching into three specific needs. They are knowledge, attitudes and willingness for teaching collaboration to implement inclusive education programs in schools. The study survey was conducted using a set of questionnaire. The study sample was selected through purposive sampling method which involves 70 people comprising special education teachers and mainstream teachers in Hulu Langat, Selangor, Malaysia. Quantitative data were analyzed descriptively using mean score and standard deviation. The findings show that the level of collaborative needs in teaching for SET and MT is at high level for knowledge aspect (mean = 3.04; sd $=0.357$ ) and willingness (mean $=3.13 ; \mathrm{sd}=0.459$ ) and attitude at medium level (mean= 2.61 and $\mathrm{sd}$ $=0.297$ ). Implications of the study show the need for enhancement of collaboration in the aspects of knowledge, readiness and attitude for an effective implementation of inclusive education in schools. Keywords: Collaboration, Teaching, Special Education Teachers, Mainstream Teachers, Inclusive Education
\end{abstract}

\section{Introduction}

The Inclusive Education Program (IEP) is a challenge for teachers in placing special needs students (SNS) in mainstream classroom which demand high levels of cooperation and commitment from various parties. Collaboration in the IEP implementation is a very important element to ensure the success of education transformation for all children. Thus, collaboration from various parties is crucial in the IEP, especially between mainstream teachers and special education teachers (Ali, Mustapha \& Jelas, 2006; Memisevic \& Hodzic, 2011). The barriers to engagement and learning of all students will be diminished with joint efforts from schools, community and government agencies (Jelas, 1997). Collaborative teaching is a method of teaching and learning collaboration where both mainstream 
and special education teachers mutually needed each other in their effort to help students with learning difficulties and agree to achieve the same goals (Jones et al., 2008). Collaborative teaching should be the approach that every school should use (Moore et al., 2010). Collaboration requires sharing of ideas between the mainstream and special education teachers. The teachers have their own strengths and weaknesses in ensuring the success of inclusive education.

The collaboration concepts need to be developed by teachers in an effort to increase their interest in inclusive education (Ajuwon, 2008). Hwang \& Evans (2011); Johnstone (2010) also stated that mainstream teachers specialize in academic field whereas special education teachers are knowledgeable in skills and specific processes in dealing with special students. According to (Obiakor et al, 2012; Naraian, 2010), inclusive education was found to be successful with collaboration and consultation of various parties involved. Collaborative teaching is important in providing quality learning to students with special needs (Milteniene \& Venclovaite, 2012). To ensure that the needs of students are met and to ensure good student performance are achieved, teachers now deal with challenge in using teaching content and appropriate teaching approaches in the classroom.

Inclusive Education is a field where there is a sharing of teaching of mainstream teacher and special education teacher in delivering instruction to various groups of students, including those with special needs, in a general educational environment, and in a flexible way and fulfilling learning needs (Friend et al, 2012). Teachers will be more prepared to teach when acquiring information or knowledge about the subject being taught as well as their students. Collaboration requires sharing in thoughts between mainstream teachers and special education teachers (Jones et al, 2008). With regard to teaching approach, appropriate collaborative teaching is when it is implemented in Inclusive Education context with the presence of skills from special education teacher and academic knowledge from mainstream teachers (Jones et al, 2008). Inclusive Education is very challenging. Thus it highly demands for both special education and mainstream teachers to commit with high levels of collaboration and understand the need for appropriate teaching approaches for Students with Special Needs (SSN) in mainstream classes in providing the best education for inclusive students.

Bashan \& Holsblat (2012) stress that collaborated teaching is difficult especially for teachers who are firmly engaged in planning and working alone where in reality they need to cooperate with other teachers when teaching in the Inclusive classroom. Collaborated teaching exists when the teachers are together in their planning, teaching and assessing the students' achievement (Murawski, \& Hughes, 2009) and (Takala \& Uusitalo-Malmivaraa, 2012).When teachers collaborate, they will share experiences, knowledge that will help them to strengthen learning and subsequently improve students achievement. Shin, Lee \& McKenna (2016) research emphasizes that special education teachers were found to be lack of knowledge about subject content to be taught to mainstream and special students. Additionally, the mainstream teachers need more training on IEP. In fact, both mainstream and special education teachers are mutually dependent for teaching approaches in the Inclusive classrooms.

A study by Gurgur \& Uzuner (2010) demonstrates that teacher's attitude plays an important role in collaborative teaching practice. Other studies have also shown that collaborative teaching will bring benefits to student's achievement and teacher's professional development (Hang \& Rabren, 2009; Matsropieri et al, 2005). Malian \& McRae (2010) in their study proves positive attitude between special education teachers and mainstream teachers for collaborative teaching. Another study also shows that teachers who are involved in shared teaching experience will be more positive than teachers who are not involved with co-teaching (Pancsofar \& Petroff, 2016; Solis et al, 2012). A 
INTERNATIONAL JOURNAL OF ACADEMIC RESEARCH IN BUSINESS AND SOCIAL SCIENCES Vol. 10, No. 8, 2020, E-ISSN: 2222-6990 @ 2020 HRMARS

research by Pancsofar \& Petroff (2016) has proven that teachers with negative attitudes towards joint teaching will prefer to use less collaborative approaches in teaching with only one teacher playing the active role while the other is passive in the inclusive class. A study by Keefe \& Moore (2004) states that in reality teachers in schools are not prepared to put collaborated teaching practice in their partnership throughout the course of collaborative teaching.

\section{Problem Statement}

The Malaysian Education Development Plan (MEDP) has targeted 30\% of students' involvement in inclusive education at the first wave (2013 - 2015) to be achieved by schools. In fact, data taken from the Malaysia Education Blueprint 2012-2025 shows that the percentage was lower with only six percent of SSN being placed under the IEP and the remaining others were placed in the Integrated Special Education program and Special Education schools (Ministry of Education, 2013).The placement rate for SSN in the IEP is very small in number compared to other SSN in integration classrooms. It is such a loss to find that IEP implementation in schools is still underdeveloped. It was found that the SSN who are supposed to learn in inclusive class were neglected and have to study with their peers in the integration class. The question is now whether Malaysia will be able to achieve $75 \%$ of SSN students in the IEP for the upcoming third wave of MEDP (2021 - 2025).

Inclusive education in Malaysia is still far from reaching the satisfactory level like in the Western countries, especially in the IEP collaborative teaching. The high collaboration gap between special education teachers (SET) and mainstream teachers (MT) in the IEP implementation requires constant need for transformation in education with collaboration from different expertise. Aspects of knowledge are needed for lesson delivery with emphasis on variety learning needs of the students (Noorafiza \& Rosadah, 2017). It was found that teachers were less knowledgeable on IEP and lack of proper training (Memisevic \& Hodzic, 2011; Ocloo \& Subbey, 2008; Khochen \& Radford, 2012). There is a decline of motivation from mainstream teachers due to lack of experience in dealing with SSN, training, understanding of inclusive concepts and external supports (Ajodhia-Andrews \& Frankel, 2010). Thus, the expected success of an inclusive education is indirectly difficult for the schools to achieve (Ajodhia-Andrew \& Frankel, 2010; Paliokosta \& Blandford, 2010).

The emphasis given by the ministry is to ensure that teachers should be prepared to play their role as facilitators for an effective learning and teaching (Ministry of Education, 2013). It is found that traditional education is still widely practiced in Malaysia resulting to the teachers involved in Inclusive Education prefer to work independently in their respective classes with their students. The teachers should change to joint teaching approaches (Memisevic \& Hodzic, 2011). Co-teaching should be a teacher's choice in helping students in an inclusive class (Friend et al, 2010) but according to Hwang \& Evans (2011). Hwang \& Evans (2011) MT are uncomfortable when SET are in their class during learning and teaching session. The implementation of inclusive education is also influenced by attitude of the teachers involved. There will be negative attitude emerged if they do not have the skills to handle SSN in an inclusive class (Sheehy et al., 2005). Teachers who prefer to teach alone tend to be negative towards IEP as opposed to voluntary teaching teachers (Pancsofar \& Petroff, 2016; Solis et al, 2016). This opinion was further supported by Naraian, (2010) who stated that teachers who are involved in the IEP were not actively oriented in the actual teaching activities. Dissatisfaction could emerge if they find professional support does not help them to change their 
INTERNATIONAL JOURNAL OF ACADEMIC RESEARCH IN BUSINESS AND SOCIAL SCIENCES

Vol. 10, No. 8, 2020, E-ISSN: 2222-6990 @ 2020 HRMARS

teaching (Diana, 2014). Without strong collaboration, will Malaysia be able to achieve up to $75 \%$ of participation from SSN in inclusive education for the upcoming third wave of MEDP (2021- 2025)?

\section{Study Objectives}

The purpose of the study was to identify the collaborative aspects in teaching needed by special education teachers and mainstream teachers in the teaching of inclusive education programs in terms of knowledge, attitudes and readiness.

\section{Research Methodology}

The study survey method uses questionnaire instrument on special education teachers (SET) and mainstream teachers (MT) in primary schools. The study involved 7 primary schools in Hulu Langat District, Malaysia and 70 teachers are involved as research samples. Questionnaires constructed by Milteniene \& Venclovate (2012) were adapted and used as main reference to construct a set of questions for the purpose of this study. This study obtained the alpha Cronbach reliability value of 0.869. The data were processed using SPSS 23.0 and analyzed using descriptive statistic to report on mean score and standard deviation.

\section{Results and Discussion}

Table 1: The Aspect of Knowledge

\begin{tabular}{|l|l|l|l|l|}
\hline No & Item & mean & sd & Level \\
\hline 1 & $\begin{array}{l}\text { I was briefed on the implementation of inclusive } \\
\text { education before it is carried out. }\end{array}$ & 3.08 & 0.812 & High \\
\hline 2 & $\begin{array}{l}\text { I am directly involved in meetings on inclusive } \\
\text { education at school. }\end{array}$ & 2.90 & 0.919 & Moderate \\
\hline 3 & $\begin{array}{l}\text { I was given detailed explanation on the concepts } \\
\text { and goals of inclusive education }\end{array}$ & 2.94 & 0.778 & Moderate \\
\hline 4 & $\begin{array}{l}\text { I should be provided with a Letter from the } \\
\text { Ministry of Education (MOE) regarding inclusive } \\
\text { education as a guide }\end{array}$ & 3.17 & 0.701 & High \\
\hline 5 & $\begin{array}{l}\text { I should be supplied with the Inclusive Education } \\
\text { Program Guidelines from the Ministry of Education } \\
\text { Malaysia (MOE) as reference. }\end{array}$ & 3.37 & 0.569 & High \\
\hline 6 & I was given an Inclusive teaching schedule & 3.04 & 0.788 & High \\
\hline 7 & $\begin{array}{l}\text { I should have been exposed to the teaching } \\
\text { method required in the Inclusive class. }\end{array}$ & 3.49 & 0.531 & High \\
\hline 8 & $\begin{array}{l}\text { I was given a comprehensive picture on strengths } \\
\text { and weaknesses of the students in inclusive } \\
\text { classroom }\end{array}$ & 3.07 & 0.804 & High \\
\hline Overall & 3.13 & 0.459 & High \\
\hline
\end{tabular}

Table I shows that each item in the construct of teacher's specific needs from the aspect of knowledge is at moderate and high level. Item with the highest mean is item 7 ' I should be given exposure on the teaching method required in the Inclusive class' shows the score (mean $=3.49 ; \mathrm{s} . \mathrm{d}=0.531$ ) is at high level. While item 2 has the lowest mean which is 'I was directly involved in the inclusive 
INTERNATIONAL JOURNAL OF ACADEMIC RESEARCH IN BUSINESS AND SOCIAL SCIENCES Vol. 10, No. 8, 2020, E-ISSN: 2222-6990 @ 2020 HRMARS

education meeting at school' (mean $=2.90 ; \mathrm{s.d}=0.919$ ) is at moderate level. Overall, the level of collaborative needs in teaching by SET and MT from knowledge aspect is at high level with a mean score of 3.13 and standard deviation, 0.459 .

Table II: The Aspect of Attitudes

\begin{tabular}{|l|l|l|l|l|}
\hline No & Item & mean & sd & Level \\
\hline 9 & $\begin{array}{l}\text { I feel collaboration is impossible in finding new } \\
\text { skills and real competition will take place. }\end{array}$ & 2.04 & 0.806 & Moderate \\
\hline 10 & $\begin{array}{l}\text { I believe that collaboration is necessary for } \\
\text { everyone to achieve shared goals }\end{array}$ & 3.39 & 0.597 & High \\
\hline 11 & $\begin{array}{l}\text { I believe that students will obtain good } \\
\text { achievement through collaboration with other } \\
\text { teachers in teaching }\end{array}$ & 3.39 & 0.519 & High \\
\hline 12 & $\begin{array}{l}\text { When I collaborate, I can hardly share my } \\
\text { teaching experience }\end{array}$ & 2.20 & 0.773 & Moderate \\
\hline 13 & $\begin{array}{l}\text { I need more effort to collaborate with teachers } \\
\text { involved in inclusive education and it is a difficult } \\
\text { process for me. }\end{array}$ & 2.56 & 0.735 & Moderate \\
\hline 14 & $\begin{array}{l}\text { In reality, all teachers can work alone and do not } \\
\text { feel the need for joint teaching with other } \\
\text { teachers to teach in the Inclusive class }\end{array}$ & 2.03 & 0.772 & Moderate \\
\hline 15 & $\begin{array}{l}\text { I think collaborative teaching is just a waste of } \\
\text { time. }\end{array}$ & 1.85 & 0.621 & Low \\
\hline 16 & $\begin{array}{l}\text { It's good for me to work alone in teaching } \\
17\end{array}$ & $\begin{array}{l}\text { I think teaching together will provide } \\
\text { opportunities for mainstream teachers and } \\
\text { Special Education teachers to learn from each } \\
\text { other in teaching techniques }\end{array}$ & 3.33 & 0.557 \\
\hline 18 & $\begin{array}{l}\text { I believe that teaching together in the classroom } \\
\text { will give more efficient support to students, } \\
\text { especially to special students. }\end{array}$ & 3.37 & 0.569 & High \\
\hline $0 v e r a l l$ & 2.61 & 0.297 & Moderate \\
\hline
\end{tabular}

Table II shows that each item for attitudes is at low, medium and high level. There are 2 items that share the same value. They are item 10 and 11. Both items have the highest mean which are 'I see collaboration is necessary for everyone to get together' and 'I believe that good achievement will be obtained by students through collaboration with other teachers in teaching' (mean = 3.39; s.d = 0.597 ) is at a high level. While item 15 has the lowest mean which is 'I think collaborative teaching together is just a waste of time' (mean $=1.85$; s.d=0.621) which is at low level. Overall, the level of teacher's needs with regard to attitude in collaborative teaching for the IEP implementation is at a moderate level ( mean $=2.61$ and $\mathrm{s} . \mathrm{d}=0.297$ ). 
INTERNATIONAL JOURNAL OF ACADEMIC RESEARCH IN BUSINESS AND SOCIAL SCIENCES Vol. 10, No. 8, 2020, E-ISSN: 2222-6990 @ 2020 HRMARS

\section{Table III: The Aspect of Readiness}

\begin{tabular}{|l|l|l|l|l|}
\hline No & Item & mean & sd & Level \\
\hline 20 & $\begin{array}{l}\text { I was given enough space and time to interact } \\
\text { with mainstream / special education teachers }\end{array}$ & 2.83 & 0.742 & Moderate \\
\hline 21 & $\begin{array}{l}\text { Collaborative teaching is a professional } \\
\text { I am willing to share my expertise on providing } \\
\text { special needs learning module. }\end{array}$ & 3.01 & 0.551 & High \\
\hline 22 & $\begin{array}{l}\text { I accept the presence of other teachers in the } \\
\text { classroom during the learning process }\end{array}$ & 3.04 & 0.550 & High \\
\hline 23 & $\begin{array}{l}\text { I am willing to change my teaching techniques } \\
\text { and strategies to ensure that students with } \\
\text { special needs can easily understand }\end{array}$ & 3.16 & 0.404 & High \\
\hline 24 & $\begin{array}{l}\text { I am willing to be an active teacher if given the } \\
\text { opportunity to teach together. }\end{array}$ & 3.19 & 0.427 & High \\
\hline 25 & $\begin{array}{l}\text { I am willing to teach together again if given the } \\
\text { opportunity }\end{array}$ & 2.94 & 0.611 & Moderate \\
\hline 26 & $\begin{array}{l}\text { I am willing to share the results with current } \\
\text { special teachers / mainstream teachers when } \\
\text { teaching students with special needs in the } \\
\text { Inclusive class }\end{array}$ & 3.11 & 0.468 & High \\
\hline 27 & $\begin{array}{l}\text { I am willing to take turn in teaching with other } \\
\text { teachers in my class. }\end{array}$ & 2.91 & 0.588 & Moderate \\
\hline Overall & 3.04 & 0.357 & High \\
\hline
\end{tabular}

Table III shows that each item in the construct of teacher's specific needs in terms of readiness is at medium and high levels. Item 24 has the highest mean which is 'I am ready to be an active teacher if given the opportunity to teach together' with the score (mean $=3.19$; s.d $=0.427$ ) is at high level. Item 19 has the lowest mean which is 'I am given enough space and time to interact with mainstream / special education teacher' with the score (mean $=2.83$; s.d $=0.742$ ) at moderate level. Overall, the level of teacher's specific needs in terms of teacher's willingness for collaborative IEP teaching is at a high level (mean $=3.04 ;$ s.d $=0.357$ ).

For the knowledge aspect, the item with the highest mean which is 'I should be exposed to the teaching methods required in the Inclusive class' is at high level. The level of teacher's knowledge should be further enhanced to maximize concerns in inclusive education (Hussin \& Hamdan, 2016). This study supports the study of (Shin, Lee \& McKenna, 2016) which proves special education teachers lacks knowledge about subject content to be taught to mainstream students and special students, as well as mainstream teachers need more training on the IEP. Collaborative teaching exists when the teachers jointly plan, teach and evaluate students' achievement (Murawski \& Hughes, 2009; Hang \& Rabren, 2009; Ben-Yehuda, Leyser \& Last, 2010). This study supports the work conducted by Goddard, Goddard \& Tschannen-Moran (2007) which states that when teachers are collaborating, they will share their experiences and knowledge to strengthen learning and subsequently achievement of students can be improved. The following study shares the same argument stated by Gurgur \& Uzuner (2010); Murawski \& Hughes (2009). Gurgur \& Uzuner (2010) 
INTERNATIONAL JOURNAL OF ACADEMIC RESEARCH IN BUSINESS AND SOCIAL SCIENCES Vol. 10, No. 8, 2020, E-ISSN: 2222-6990 @ 2020 HRMARS

that collaboration in teaching will empower the mainstream teachers to enhance understanding on the structure, content in the curriculum while special education teachers will better understand the needs of students especially students of special education and will work together to match the necessary needs in co-teaching. Construct on teacher's special needs also shows the lowest mean item which is 'I am directly involved in the inclusive education meeting at school' is at a moderate level. This shows that teachers need less meetings to boost their knowledge on inclusive education. This study however is in conflict with a research carried out by Memisevic \& Hodzic (2011) hat argues meeting is necessary to discuss standard setting, assessment, convenience, modification, instructional strategy and class arrangement.

In terms of attitudes, item with the highest mean is 'I see collaboration is necessary for everyone to get together' and 'I believe that good achievement will be obtained by students through collaborative teaching with other teachers' with the mean of 3.39 and standard deviation of 0.597. Whereas item with the lowest mean is 'I think teaching together is only a a waste of time' (mean = 1.85 and $s . d=0.621$ ) is at low level. This study is similar to a research conducted by Gurgur and Uzuner (2010) which shows teacher's attitude play an important role in collaborative teaching practice. Malian \& McRae (2010) in their work proves there is positive attitude between special education teachers and mainstream teachers in collaboration. Shin, Lee \& McKenna, (2016) also suggests that personality is a major challenge in the implementation of co-teaching. The study was supported by Hang \& Rabren (2009); Matsropieri et al. (2005) who also stated that collaborative teaching in practice would bring benefit to student's achievement and teacher's professional development. This study is also supported by Pancsofar \& Petroff (2016); Solis et al (2012) that demonstrate teachers who are involved in joint teaching experience will have more positive attitudes than teachers who are not involved. This study, however, contradicts with that proves teachers with negative attitudes toward shared teaching will be less likely to use collaborative teaching as their teaching method. The same study by Pancsofar \& Petroff (2016) also proves that common teaching approach that is widely used is that only one teacher plays the active role while another is passive in an inclusive class.

For the aspect of readiness, the item with the highest mean is 'I am ready to be active teacher if given the opportunity to teach together' (mean $=3.19$; s.d $=0.427$ ) at high level. Whereas the item with the lowest mean which is 'I was given enough space and time to interact with mainstream / special education teacher' (mean $=2.83$; $\mathrm{s} . \mathrm{d}=0.742$ ) is at moderate level. It was found that the overall aspect of teachers in terms of readiness of teachers to collaborate in teaching for IEP is at high level ( mean $=3.03$; s.d $=0.357$ ). This means that teachers who are involved in inclusive education are better prepared to teach together in an inclusive class. The findings are similar to (Ocloo \& Subbey, 2008). study which shows that teachers have a high level of readiness in transformation of teaching strategies to ensure that understanding of students with special needs can be improved. This study is similar to the work carried out by Matsropieri et al., (2005) which proves that voluntary teachers who collaborate in teaching will show positive perception compared to teachers who are not involved with collaborative teaching. This study is contrary to the study by Keefe \& Moore (2004); Milteniene \& Venclovate (2012) who find that teachers at school are not ready to practice collaborative teaching in their partnership as they collaborate with each other. 
INTERNATIONAL JOURNAL OF ACADEMIC RESEARCH IN BUSINESS AND SOCIAL SCIENCES Vol. 10, No. 8, 2020, E-ISSN: 2222-6990 @ 2020 HRMARS

\section{Conclusion}

Collaboration in teaching is very important to improve the quality of education for children with special needs who are learning in the mainstream classes. Collaborative edification in lessons needs to be given due attention to all parties concerned and they need to be fully aware on their respective roles. Overall, this study demonstrates the specific needs to form collaborative teaching among teachers involved. The implementation of inclusive education at primary school level among teachers involved is still at moderate level. Accordingly, all parties must play their role to meet the special needs in collaborative teaching.

\section{References}

Ajuwon, P. M. (2008). Inclusive Education for Students with Disabilities in Nigeria: Benefits, Challenges and Policy Implications. International journal of special education, 23(3), 11-16.

Ajodhia-Andrews, A., \& Frankel, E. (2010). Inclusive Education in Guyana: A Call for Change. International Journal of Special Education, 25(1), 126-144.

Ali, M. M., Mustapha, R., \& Jelas, Z. M. (2006). An Empirical Study on Teachers' Perceptions towards Inclusive Education in Malaysia. International journal of special education, 21(3), 36-44.

Bashan, B., \& Holsblat, R. (2012). Co-teaching through modeling processes: Professional development of students and instructors in a teacher training program. Mentoring \& Tutoring: Partnership in Learning, 20(2), 207-226.

Ben-Yehuda, S., Leyser, Y., \& Last, U. (2010). Teacher educational beliefs and sociometric status of special educational needs (SEN) students in inclusive classrooms. International Journal of Inclusive Education, 14(1), 17-34.

Diana, Jr, T. J. (2014). Co-teaching: Enhancing the student teaching experience. Kappa Delta Pi Record, 50(2), 76-80.

Friend, M., Cook, L., Hurley-Chamberlain, D., \& Shamberger, C. (2010). Co-teaching: An illustration of the complexity of collaboration in special education. Journal of educational and psychological consultation, 20(1), 9-27.

Goddard, Y. L., Goddard, R. D., \& Tschannen-Moran, M. (2007). A theoretical and empirical investigation of teacher collaboration for school improvement and student achievement in public elementary schools. Teachers college record, 109(4), 877-896.

Gurgur, H., \& Uzuner, Y. (2010). A Phenomenological Analysis of the Views on Co-teaching Applications in the Inclusion Classroom. Educational sciences: Theory and practice, 10(1), 311331.

Hang, Q., \& Rabren, K. (2009). An examination of co-teaching: Perspectives and efficacy indicators. Remedial and Special Education, 30(5), 259-268.

Hussin, M. K. A. B., \& Hamdan, A. R. B. (2016). Effect of Knowledge, Readiness and Teaching Technique in Inclusive Practices Among Mainstream Teachers in Malaysia. International Journal of Early Childhood Special Education, 8(1).

Hwang, Y. S., \& Evans, D. (2011). Attitudes towards inclusion: Gaps between belief and practice. International journal of special education, 26(1), 136-146.

Jelas, Z. M. (1997). Ke-arah pendidikan inklusif di Malaysia melalui kerjasama antarabangsa. In Seminar Kebangsaan Pendidikan Guru. Serdang: Universiti Pertanian Malaysia. 
INTERNATIONAL JOURNAL OF ACADEMIC RESEARCH IN BUSINESS AND SOCIAL SCIENCES

Vol. 10, No. 8, 2020, E-ISSN: 2222-6990 @ 2020 HRMARS

Johnstone, C. J. (2010). Inclusive Education Policy Implementation: Implications for Teacher Workforce Development in Trinidad and Tobago. International journal of special education, 25(3), 33-42.

Jones, M., Michael, C., Mandala, J., \& Colachico, D. (2008). Collaborative Teaching: Creating a Partnership between General and Special Education. International Journal of Learning, 15(7).

Keefe, E. B., \& Moore, V. (2004). The challenge of co-teaching in inclusive classrooms at the high school level: What the teachers told us. American secondary education, 77-88.

Khochen, M., \& Radford, J. (2012). Attitudes of teachers and headteachers towards inclusion in Lebanon. International Journal of Inclusive Education, 16(2), 139-153.

Malian, I., \& McRae, E. (2010). Co-teaching beliefs to support inclusive education: Survey of relationships between general and special educators in inclusive classes. Electronic Journal for Inclusive Education, 2(6), 2.

Miltenienè, L., \& Venclovaitè, I. (2012). TEACHER COLLABORATION IN THE CONTEXT OF INCLUSIVE EDUCATION. Special Education, (2).

Mastropieri, M. A., Scruggs, T. E., Graetz, J., Norland, J., Gardizi, W., \& Mcduffie, K. (2005). Case studies in co-teaching in the content areas: Successes, failures, and challenges. Intervention in school and clinic, 40(5), 260-270.

Memisevic, H., \& Hodzic, S. (2011). Teachers' attitudes towards inclusion of students with intellectual disability in Bosnia and Herzegovina. International Journal of Inclusive Education, 15(7), 699710.

Moore-Thomas, C., \& Day-Vines, N. L. (2010). Culturally competent collaboration: School counselor collaboration with African American families and communities. Professional School Counseling, 14(1), 2156759X1001400106.

Murawski, W. W., \& Hughes, C. E. (2009). Response to intervention, collaboration, and co-teaching: A logical combination for successful systemic change. Preventing School Failure: Alternative Education for Children and Youth, 53(4), 267-277.

Naraian, S. (2010). General, special and... inclusive: Refiguring professional identities in a collaboratively taught classroom. Teaching and Teacher Education, 26(8), 1677-1686.

Obiakor, F. E., Harris, M., Mutua, K., Rotatori, A., \& Algozzine, B. (2012). Making inclusion work in general education classrooms. Education and Treatment of Children, 35(3), 477-490.

Ocloo, M. A., \& Subbey, M. (2008). Perception of basic education school teachers towards inclusive education in the Hohoe District of Ghana. International Journal of Inclusive Education, 12(56), 639-650.

Paliokosta, P., \& Blandford, S. (2010). Inclusion in school: a policy, ideology or lived experience? Similar findings in diverse school cultures. Support for Learning, 25(4), 179-186.

Pancsofar, N., \& Petroff, J. G. (2016). Teachers' experiences with co-teaching as a model for inclusive education. International Journal of Inclusive Education, 20(10), 1043-1053.

Sheehy, K., Nind, M., Rix, J., \& Simmons, K. (Eds.). (2005). Ethics and research in inclusive education: Values into practice. Psychology Press.

Shin, M., Lee, H., \& McKenna, J. W. (2016). Special education and general education preservice teachers' co-teaching experiences: A comparative synthesis of qualitative research. International Journal of Inclusive Education, 20(1), 91-107.

Solis, M., Vaughn, S., Swanson, E., \& McCulley, L. (2012). Collaborative models of instruction: The empirical foundations of inclusion and co-teaching. Psychology in the Schools, 49(5), 498-510. 
INTERNATIONAL JOURNAL OF ACADEMIC RESEARCH IN BUSINESS AND SOCIAL SCIENCES Vol. 10, No. 8, 2020, E-ISSN: 2222-6990 @ 2020 HRMARS

Stumpf, J. A. (2015). A Case Study of Co-Teaching Practices in Minnesota.

Stuart, S. K., \& Rinaldi, C. (2009). A collaborative planning framework for teachers implementing tiered instruction. Teaching Exceptional Children, 42(2), 52-57.

Takala, M., \& Uusitalo-Malmivaara, L. (2012). A one-year study of the development of co-teaching in four Finnish schools. European Journal of Special Needs Education, 27(3), 373-390. 